Fikroh : Jurnal Pemikiran dan Pendidikan Islam

Volume. 14, Number. 1, Januari 2021

p-ISSN : 2087-7501, e-ISSN : 2715-4459

HIm : 79-88

Journal Home Page : https://jurnal.stai-alazharmenganti.ac.id/index.php/fikroh

\title{
PENGEMBANGAN BAHAN AJAR TEMATIK TERPADU BERBASIS MODEL RECIPROCAL TEACHING UNTUK SISWA KELAS IV SEKOLAH DASAR
}

\author{
Dina Dahliana \\ STAI Solok Nan Indah, Solok, Indonesia \\ dinadahlianastaisni1@gmail.com \\ Pio Anggraini \\ Mahasiswa STKIP Adzkia, Padang, Indonesia \\ Pioanggraini01@gmail.com
}

\begin{abstract}
Development of integrated thematic teaching materials based on reciprocal teaching models for grade iv elementary school. Teachers are very involved in developing effective teaching materials for the progress of students in learning. Meanwhile, the existing teaching materials still need improvements because there are several errors such as paragraphs in the reading that are not aligned left-right, capital letters errors. Therefore, to solve this problem, it is necessary to find a solution in the form of developing integrated thematic teaching materials based on the reciprocal teaching model for grade IV elementary school students. This articles aims to produce valid teaching materials. This type of research is development research using the 4-D model (four D models). The model consists of four stages, namely defining (defining), designing (designing), developing (developing), and spreading (deseminating). The results showed that the integrated thematic teaching materials using the reciprocal teaching model obtained the proportion of validity of teaching materials and lesson plans were $87.5 \%$ (material) with a very valid category, $75 \%$ (language) with a valid category, and $81.8 \%$ (design). with a very valid category. While the proportion of RPP is $90 \%$ with very valid category.
\end{abstract}

Keywords: Development; Teaching materials; Integrated Thematic; Reciprocal Teaching Model.

\begin{abstract}
Abstrak
Guru sangat berperan dalam mengembangkan bahan ajar yang efektif untuk mendorong kemajuan peserta didik dalam belajar. Sementara itu bahan ajar yang ada masih perlu perbaikan-perbaikan karena terdapat beberapa kesalahan seperti paragraf dalam teks bacaan belum rata kiri-kanan, kesalahan penulisan
\end{abstract}


huruf kapital. Oleh sebab itu, untuk mengatasi permasalahan tersebut, perlu dicari solusi berupa pengembangan bahan ajar tematik terpadu berbasis model reciprocal teaching untuk siswa kelas IV Sekolah Dasar. Penelitian ini bertujuan untuk menghasilkan bahan ajar yang valid. Jenis penelitian yang digunakan adalah penelitian pengembangan dengan menggunakan model 4-D (four $\mathrm{D}$ model). Model ini terdiri dari empat tahap yaitu pendefinisian (define), perancangan (design), pengembangan (develop), dan penyebaran (desseminate). Hasil penelitian menunjukkan bahwa bahan ajar tematik terpadu menggunakan model reciprocal teaching yang dikembangkan memperoleh persentase kevalidan bahan ajar dan RPP adalah 87,5\% (materi) dengan kategori sangat valid, 75\% (bahasa) dengan kategori valid, dan 81,8\% (desain) dengan kategori sangat valid. Sedangkan persentase RPP adalah 90\% dengan kategori sangat valid.

Kata kunci: Pengembangan Bahan Ajar; Tematik Terpadu; Model Reciprocal Teaching

\section{A. Pendahuluan}

Dalam kurikulum 2013 kegiatan pembelajaran di Sekolah Dasar kelas I sampai VI dilakukan dengan menggunakan pembelajaran tematik terpadu. Pemerintah merancang pembelajaran abad 21 melalui kurikulum 2013 yang berbasis pada peserta didik. Pendidik sebagai tangan kanan dari pemerintah di sekolah-sekolah menerapkan kemampuan 4C (Critical Thinking, Communicaion, Callaboration, Creativity). Pembelajaran tematik terpadu bermakna karena peserta didik akan memahami konsep-konsep yang mereka pelajari melalui pengalaman langsung dan menghubungkannya dengan konsep lain yang telah dipahami. ${ }^{1}$

Proses pembelajaran tematik terpadu di Sekolah Dasar lebih bergantung pada kondisi sekolah, baik yang menyangkut metode maupun bahan ajar. Secara umum pembelajaran di Sekolah Dasar masih disampaikan secara konvensional, masih didominasi ceramah walaupun kadang ada yang menggunakan diskusi, hanya sedikit sekolah yang menetapkan metode pendekatan ilmiah seperti praktikum ataupun demonstrasi. Semua itu terkendala pada keterbatasan bahan ajar, apalagi Sekolah Dasar di daerah terpencil. Keadaan ini membuat pendidik Sekolah Dasar mengandalkan sepenuhnya pada buku paket yang bersumber dari Dinas Pendidikan Nasional atau Departemen Pendidikan, dan buku teks lainnya.

\footnotetext{
${ }^{1}$ Rusman, Pembelajaran Tematik Terpadu : Teori, Praktik dan Penilaian (Jakarta: Rajawali Pres, 2015), 33.
} 


\section{$\longrightarrow$ Jurnal Pemikiran dan Pendidikan Islam}

Pengembangan Bahan Ajar...

Sebagai pendidik, bahan ajar dalam hal-hal tertentu bisa mewakili pendidik dalam menyajikan materi pembelajaran kepada peserta didik. Jika bahan ajar yang digunakan itu dirancang dan dikembangkan secara baik, maka fungsi itu akan dapat diperankan oleh pendidik meskipun tanpa keberadaan pendidik. Akan tetapi, dalam realita pendidikan di lapangan penulis melihat pendidik yang masih menggunakan bahan ajar yang konvensional, yaitu bahan ajar tinggal pakai, tinggal beli, instan, serta tanpa upaya merencanakan, menyiapkan dan menyusunnya sendiri.

Permasalahan senada juga terdapat dalam penelitian Silviana Nasrul dan Silfi Melindawati yang mengungkapkan bahwa buku siswa masih perlu dikembangkan agar sesuai dengan yang diharapkan. Resikonya sangat dimungkinkan jika bahan ajar yang mereka pakai itu tidak kontekstual, tidak menarik, monoton, dan tidak sesuai dengan kebutuhan peserta didik. Agar peserta didik dapat belajar dengan baik maka bahan ajar yang digunakan harus tepat, valid, sesuai dengan gaya belajar dan perkembangan peserta didik. $^{2}$

Dalam pembelajaran tematik terpadu dimana satu tema dibuat untuk menyatukan beberapa isi pembelajaran sekaligus. Secara umum pelaksanaan pembelajaran tematik terintegrasi belum berjalan secara optimal karena beberapa kendala, seperti bahan ajar yang digunakan tidak menjadikan siswa aktif. Intinya kegiatan dalam pembelajaran yang ada pada bahan ajar tidak melibatkan siswa secara aktif. Hal tersebut berdampak pada kesulitan siswa dalam memahami isi bacaan yang terdapat pada bahan ajar. ${ }^{3}$

Materi-materi yang terdapat dalam bahan ajar masih belum cukup untuk diajarkan kepada peserta didik. Oleh sebab itu, sangat dianjurkan para pendidik untuk mengembangkan bahan ajar yang lebih memadai. ${ }^{4}$ Selain itu, kalimat-kalimat dalam bahan ajar juga perlu diperbaiki; penulisan paragraf yang belum rata kiri-kanan; dan penulisan

\footnotetext{
2 Silviana Nasrul, "Pengembangan Bahan Ajar Tematik Terpadu Berbasis Model Problem Based Learning di Kelas Iv Sekolah Dasar," Jurnal Inovasi Pendidikan Dan Pembelajaran Sekolah Dasar, 2, No. 1(2018): 56-57, https://doi.org/10.24036/jippsd.v2i1.100491.

3 D Dahliana, "Teaching Materials of Silent Reading With The Ok5r Strategy For Elementary School Students In The Era Of Revolution 4.0. In Eighth International Conference On Languages And Arts (Icla2019) (Pp. 59-62). Atlantis Press," Accessed 2020, August, [https://doi.org/10.2991/assehr.k.200819.012].

4 E Eliyanti, Taufina T, \& Hakim R., "Pengembangan Bahan Ajar Keterampilan Menulis Narasi dengan Menggunakan Mind Mapping dalam Pembelajaran Tematik di Sekolah Dasar," Jurnal Basicedu, 4, No. 4 (2020): 838-849, https://doi.org/10.31004/basicedu.v4i4.439.
} 
pada huruf kapital yang masih perlu untuk diperbaiki. Kesalahan tersebut dapat tergambar pada gambar berikut :

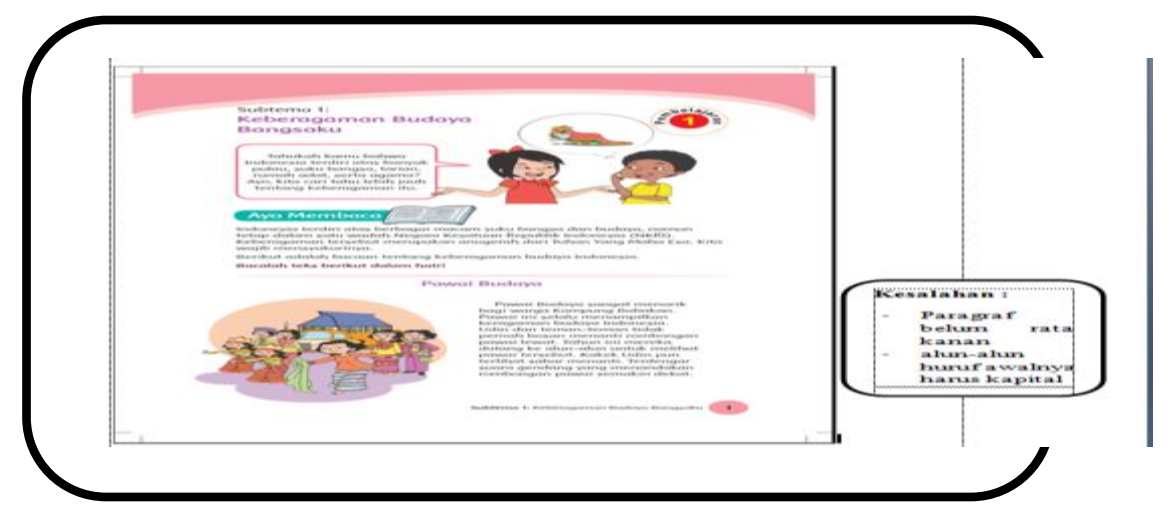

Gambar 1. Buku Siswa yang ada di Sekolah

Bahan ajar di atas merupakan salah satu kesalahan yang penulis temukan, maka masih sangat diperlukan untuk dilakukan perbaikan demi kesempurnaan bahan ajar tersebut. Bahan ajar yang baik mesti menggunakan tata penulisan yang benar, seperti penggunaan huruf, gaya bahasa, dan lain sebagainya. ${ }^{5}$ Penulis telah melaksanakan analisis kebutuhan terhadap beberapa guru kelas IV Sekolah Dasar, maka diperoleh kesimpulan bahwa para pendidik di beberapa sekolah tersebut belum menerapkan model pembelajaran reciprocal teaching. Maka penulis akan melakukan pengembangan bahan ajar yang berbasis model tersebut.

Berdasarkan uraian di atas salah satu cara yang dapat dilakukan untuk peserta didik dalam belajar adalah dengan memberikan bahan ajar yang relevan untuk diterapkan oleh pendidik. Selain itu, model yang digunakan dalam proses pembelajaran juga sangat berpengaruh dalam meningkatkan pemahaman peserta didik dalam pembelajaran. Salah satu model yang dapat membantu pendidik dalam proses belajar mengajar adalah menggunakan model Reciprocal Teaching. Model Reciprocal teaching merupakan salah satu model pengajaran yang menekankan pada pemahaman dalam membaca. Pembelajaran Reciprocal Teaching digunakan untuk membantu peserta didik memusatkan perhatian pada apa yang sedang dibaca dan membuat siswa memahami bacaannya. ${ }^{6}$

\footnotetext{
${ }^{5}$ E T Bahtiar, "Penulisan bahan ajar: Pelatihan Penyusunan Bahan Ajar untuk Mendukung Pelaksanaan Tri Dharma Perguruan Tinggi," accessed 2015.

${ }^{6}$ F E Kurniawati, "Pengembangan Bahan Ajar Aqidah Ahklak di Madrasah Ibtidaiyah," Jurnal Penelitian, 9, No. 2 (2015): 367, https://doi.org/10.21043/jupe.v9i2.1326.
} 


\section{$\longrightarrow$ Jurnal Pemikiran dan Pendidikan Islam}

Pengembangan Bahan Ajar...

Model pembelajaran reciprocal teaching berperan dalam merangsang peserta didik untuk belajar mandiri, kritis dan lebih aktif dalam mengikuti pembelajaran. Model pembelajaran ini menerapkan empat langkah yaitu membuat pertanyaan, memprediksi, mengklarifikasi, dan merangkum. Pemilihan model pembelajaran ini harus diimbangi dengan bahan belajar yang memadai. Sehingga diharapkan mampu menciptakan suasana pembelajaran yang lebih bermakna dan memberi kesan yang kuat kepada peserta didik.

\section{B. Metode Penelitian}

Penelitian ini merupakan penelitian pengembangan (Research and Development) untuk menghasilkan suatu produk baru, yaitu produk pembelajaran menggunakan reciprocal teaching. Penelitian pengembangan adalah upaya untuk mengembangkan dan menghasilkan suatu produk berupa perangkat pembelajaran yang digunakan untuk mengatasi permasalahan pembelajaran di kelas dan bukan menguji teori. Penelitian pengembangan adalah suatu proses dan langkah-langkah untuk mengembangkan suatu produk baru atau menyempurnakan produk yang telah ada. ${ }^{7}$ Pengembangan bahan ajar tematik terpadu ini menggunakan reciprocal teaching menggunakan model 4-D (four D model), yang dikemukakan oleh S.Thiagarajan, Dorothy S. Semmel, dan Melvyn I Semmel. Model ini terdiri dari empat tahap yaitu pendefinisian (define), perancangan (design), pengembangan (develop), dan penyebaran (desseminate). ${ }^{8}$

\section{Hasil dan Pembahasan}

Pengembangan bahan ajar dengan menggunakan model cooperative script dalam pembelajaran tematik terpadu dengan menggunakan model 4D telah berhasil dilaksanakan dengan baik. Bahan ajar dengan menggunakan model cooperative script dalam pembelajaran tematik terpadu telah dikembangkan dengan tingkat kevalidannya sangat valid. Pengembangan bahan ajar dengan model cooperative script dalam pembelajaran tematik terpadu bertujuan untuk menghasilkan bahan ajar yang valid. Bahan ajar dalam pembelajaran tematik terpadu yang dirancang dikembangkan dengan menggunakan model

\footnotetext{
${ }^{7}$ N M Faqih, \& Fauzi N., "Pengembangan Bahan Ajar Buku Teks IPS Tema Indahnya Kebersamaan Pada Peserta Didik Kelas 4 MI An Nuriyah Kwanyar Bangkalan," FIKROH: Jurnal Pemikiran dan Pendidikan Islam, 13, No. 2 (2020): 132-143, https://doi.org/10.37812/fikroh.v13i2.98.

8 Trianto, Model Pembelajaran Terpadu, (Jakarta: PT Bumi Aksara, 2012), 25.
} 
pengembangan 4D yaitu 1) tahap pendefinisian (define), 2) tahap perancangan (design), 3) tahap pengembangan (develop), dan 4) tahap penyebaran (dessiminate). Setelah melakukan tahap tersebut maka diperoleh bahan ajar dalam pembelajaran tematik terpadu yang valid hasil validasi oleh validator ahli.

Rancangan bahan ajar yang telah dikembangkan haruslah teruji kevalidannya. Bahan ajar dikatakan valid apabila memenuhi karakteristik dan kriteria tertentu. Validitas diperlukan untuk menguji suatu penelitian. Pada penelitian ini validasi dirinci menjadi validasi yang dilakukan terhadap isi, bahasa, dan kegrafikaan. Validitas bahan ajar dengan model cooperative script melibatkan 3 orang validator ahli. Hasil validasi dari ahli tersebut dikumpulkan kemudian dianalisis untuk dicari rata-rata dari masing-masing indikator dan masing-masing aspek. Hasil validasi ini dipaparkan sebagai berikut:

\section{Validasi RPP}

Validasi RPP disesuaikan dengan komponen RPP, yaitu: identitas, perumusan tujuan pembelajaran, pemilihan materi pembelajaran, metode dan kerincian langkahlangkah pembelajaran, pemilihan sumber belajar, dan penilaian. Perancangan RPP disesuaikan dengan prinsip-prinsip RPP. Perancangan RPP dikatakan valid apabila telah sesuai dengan pendapat yang dikemukakan para ahli. Proses validasi rencana pelaksanaan pembelajaran dilakukan oleh 1 orang validator dengan berpedoman kepada prinsip dan komponen RPP, maka RPP yang telah dikembangkan masuk ke dalam kategori sangat valid. RPP yang telah dikembangkan menggambarkan kesesuaian seluruh komponen dan kegiatan serta konsep yang telah terkandung di dalamnya. Kesesuaian itu terlihat dari indikator dan tujuan pembelajaran yang telah dirumuskan, materi yang dipilih, komponen model cooperative script yang digunakan, langkah-langkah pembelajaran, media dan sumber belajar, serta penilaian yang dilakukan. Artinya, secara umum telah dapat menggambarkan komponen RPP yang sesuai dengan permendikbud Nomor 22 tahun 2016.

\section{Validasi bahan ajar}

Bahan ajar yang telah dikembangkan dikatakan valid apabila memenuhi kriteria tertentu. Kriteria yang dimaksud seperti yang disampaikan oleh Plomp (2012) bahwa karakteristik dari produk yang dikatakan valid apabila terdapat merefleksikan 


\section{$\longrightarrow$ Jurnal Pemikiran dan Pendidikan Islam}

Pengembangan Bahan Ajar...

pengetahuan (state of the art knowledge). Oleh sebab itu, validasi yang dilakukan terhadap bahan ajar dengan model cooperative script dalam pembelajaran tematik terpadu menekankan pada validitas isi/materi/konten, bahasa, dan desain.

Validitas isi telah dinyatakan valid oleh validator karena bahan ajar yang dikembangkan telah sesuai dengan materi yang sebenarnya pada pembelajaran tematik terpadu di kelas IV SD. Validitas bahasa dinyatakan valid apabila bahan ajar yang dikembangkan telah menggunakan bahasa-bahasa yang sesuai dengan peserta didik kelas IV SD. Validitas desain bahan ajar dinyatakan valid oleh validator apabila bahan ajar telah dikembangkan dapat menarik perhatian siswa untuk belajar. Berdasarkan analisis data penilaian validasi oleh validator, bahan ajar membaca tersebut yang dikembangkan tergolong sangat valid.

Berdasarkan hasil analisis data validasi bahan ajar oleh para ahli diperoleh persentase $87,5 \%$ (materi) dengan kategori sangat valid, 75\% (bahasa) dengan kategori valid, dan $81,8 \%$ (desain) dengan kategori sangat valid. Jika dilihat dari kategori yang telah dikembangkan tergolong pada kategori sangat valid. Oleh sebab itu bisa disimpulkan bahwa bahan ajar yang dikembangkan telah sesuai dengan tuntutan kurikulum. Penyajian materi telah sesuai dengan indikator yang dirumuskan dan sesuai dengan perkembangan peserta didik.

Isi bahan ajar juga telah sesuai dengan materi pembelajaran tematik terpadu di kelas IV SD. Berbagai konsep dan penjabaran tugas-tugas yang terdapat dalam bahan ajar memudahkan peserta didik memahami isi teks bacaan. Isi bahan ajar telah dapat mencapai kompetensi dasar yang dipilih. Selain itu, penggunaan bahasa dalam bahan ajar menggunakan kalimat yang sederhana dan mudah dipahami oleh peserta didik. Kalimat menggunakan bahasa yang komunikatif sehingga mudah dipahami peserta didik. Kalimat demi kalimat menggunakan ejaan yang tepat. Bahan ajar yang dikembangkan didesain dengan gradasi warna yang menarik, sehingga dapat memotivasi peserta didik untuk mengikuti proses pembelajaran dengan baik. Dengan demikian, dapat disimpulkan bahwa bahan ajar yang dikembangkan telah dinyatakan valid dan dapat digunakan dalam proses pembelajaran di kelas IV Sekolah Dasar. Berikut adalah sampul (cover) bahan ajar tematik terpadu yang dikembangkan. 


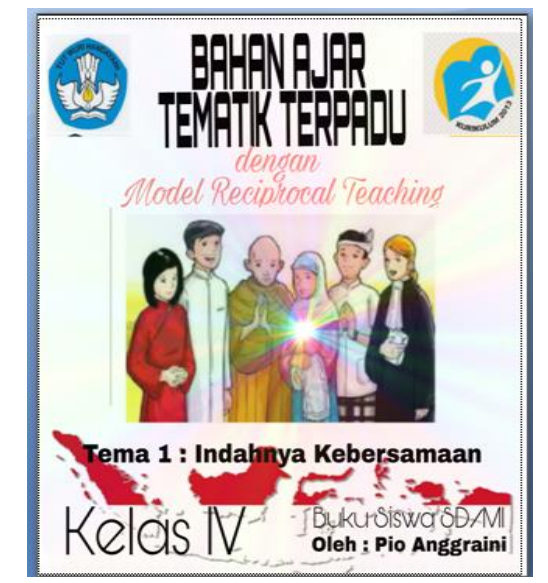

Gambar 2. Sampul bahan ajar

\section{Simpulan}

Berdasarkan pengembangan dan validitas bahan ajar, maka dapat disimpulkan bahwa hasil penelitian menunjukkan bahwa bahan ajar di kelas IV SD yang dikembangkan telah valid dan dapat digunakan dalam melaksanakan proses pembelajaran di kelas. Kevalidan RPP dikarenakan telah sesuai dengan komponen-komponen yang terdapat dalam permendikbud nomor 21 tahun 2016 dan dirancang sesuai dengan model reciprocal teaching yang digunakan dalam melaksanakan pembelajaran. Bahan ajar yang dikembangkan telah sesuai dengan tuntutan kurikulum yakni kurikulum 2013, penyajian materi telah sesuai dengan indikator yang telah dirumuskan, serta materi telah sesuai dengan kompetensi yang akan dicapai. Selain itu, penggunaan bahasa dalam bahan ajar menggunakan kalimat yang sederhana dan mudah dipahami oleh peserta didik. Desain bahan ajar juga telah disesuaikan dengan karakteristik dan perkembangan peserta didik. Adapun persentase kevalidan bahan ajar dan RPP adalah 87,5\% (materi) dengan kategori sangat valid, 75\% (bahasa) dengan kategori valid, dan 81,8\% (desain) dengan kategori sangat valid. Sedangkan persentase RPP adalah 90\% dengan kategori sangat valid.

\section{E. Daftar Pustaka}

Bahtiar, E. T. "Penulisan bahan ajar: Pelatihan Penyusunan Bahan Ajar untuk Mendukung Pelaksanaan Tri Dharma Perguruan Tinggi." accessed 2015.

Dahliana, D. "Teaching Materials of Silent Reading With The Ok5r Strategy For Elementary School Students In The Era Of Revolution 4.0. In Eighth International Conference On Languages And Arts (Icla-2019) (Pp. 59-62). Atlantis Press." accessed 2020, August. [https://doi.org/10.2991/assehr.k.200819.012] 
Dewi, S. K. "Analisis Penerapan Lembar Kerja Siswa Berbasis Pendekatan Reciprocal Teaching Pada Subtema 1 Kelas III SD N Gading Kulon 02 Dau Malang." Doctoral Dissertation, University of Muhammadiyah Malang. 2017.

Eliyanti, E. Taufina T. \& Hakim R.. "Pengembangan Bahan Ajar Keterampilan Menulis Narasi dengan Menggunakan Mind Mapping dalam Pembelajaran Tematik di Sekolah Dasar." Jurnal Basicedu Vol 4, no. 4 (2020): 838-849. https://doi.org/10.31004/basicedu.v4i4.439.

Erawati, R. "Pengembangan Lembar Kegiatan Peserta Didik Berbasis Model Reciprocal Teaching Untuk Meningkatkan Kemampuan Berpikir Kritis Peserta Didik Kelas IV SD" Doctoral Dissertation, Universitas Lampung. 2019.

Faqih, N. M. \& Fauzi N. "Pengembangan Bahan Ajar Buku Teks IPS Tema Indahnya Kebersamaan Pada Peserta Didik Kelas 4 MI An Nuriyah Kwanyar Bangkalan." FIKROH: Jurnal Pemikiran dan Pendidikan Islam Vol. 13, no. 2(2020): 132143. https://doi.org/10.37812/fikroh.v13i2.98.

Hamdani. Strategi Belajar Mengajar. Bandung: Pustaka Setia, 2011.

Khairani, S. Asrizal \& Amir H. "Pengembangan Bahan Ajar Ipa Terpadu Berorientasi Pembelajaran Kontekstual Tema Pemanfaatan Tekanan Dalam Kehidupan Untuk Meningkatkan Literasi Siswa Kelas VIII SMP." Pillar of Physics Education 10(2017): 153 160. http://dx.doi.org/10.24036/2571171074.

Khasanah, U. "Pengaruh Model Reciprocal Teaching Terhadap Hasil Belajar Tematik Peserta Didik Kelas IV SD Negeri 4 Metro Barat." accessed 2019.

Kurniawati, F. E. "Pengembangan Bahan Ajar Aqidah Ahklak di Madrasah Ibtidaiyah." Jurnal Penelitian 9, no. 2(2015): 367. https://doi.org/10.21043/jupe.v9i2.1326.

Laksana, D. N. L. Kurniawan P. A. W. \& Niftalia I. "Pengembangan Bahan Ajar Tematik Sd Kelas IV Berbasis Kearifan Lokal Masyarakat Ngada." Jurnal Ilmiah Pendidikan Citra Bakti, Vol 3, no. 1 (2018): $1-10$. http://www.ejournal.citrabakti.ac.id/index.php/jipcb/article/view/74.

Majid, A. Strategi Pembelajaran. Bandung: PT Remaja Rosdakarya, 2014.

Marlaini, C. "Meningkatkan Motivasi Dan Hasil Belajar Dengan Pendekatan Reciprocal Teaching Pada Sd Muhammadiyah Banda Aceh." Serambi Ptk, Vol 5, no. 2(2018): 1823. http://ojs.serambimekkah.ac.id/serambi-ptk/article/view/856.

Melindawati, S. "Pengembangan Bahan Ajar Tematik Terpadu Dengan Model Problem Based Learning Di Kelas Iv Sekolah Dasar." Elementary School Journal Pgsd Fip Unimed, Vol 5, no. 1(2016): https://doi.org/10.24114/esjpgsd.v5i1.3974.

Murniayudi, H. Mustadi A. \& Jerusalem M. A. "Reciprocal Teaching: Sebuah Inovasi Pembelajaran Abad 21 Untuk Meningkatkan Pemahaman Konsep Mahasiswa Pgsd." Prem. Educ. J. Pendidik. Dasar Dan Pembelajaran, Vol 8, no. 2(2018): 173. https://pdfs.semanticscholar.org/a78d/e89c8f1bc2df953d0eaa23b539d3656fe9b7.pd. 
Nasrul, S. "Pengembangan Bahan Ajar Tematik Terpadu Berbasis Model Problem Based Learning Di Kelas Iv Sekolah Dasar." Jurnal Inovasi Pendidikan Dan Pembelajaran Sekolah Dasar, Vol 2, no. 1(2018): https://doi.org/10.24036/jippsd.v2i1.100491.

Ngaziz, M. "Pengembangan Bahan Ajar Tematik Terpadu Dengan Tema Pariwisata Pada Kelas Ii Mi Ma'arif Sukun I Malang" Doctoral Dissertation, Universitas Islam Negeri Maulana Malik Ibrahim. 2014.

Nurdyansyah, \& Mutala'liah, N. "Pengembangan Bahan Ajar Modul Ilmu Pengetahuan Alambagi Siswa Kelas Iv Sekolah Dasar." Program Studi Pendidikan Guru Madrasa Ibtida'iyah Fakultas Agama Islam Universitas Muhammadiyah Sidoarjo. 2018.

Rusman. Pembelajaran Tematik Terpadu: Teori, Praktik dan Penilaian. Jakarta: Rajawali Pres, 2015.

Sarwendah, S. "Peningkatan Hasil Belajar Ipa Materi Gaya Menggunakan Model Reciprocal Teaching Pada Siswa Kelas IV MI Ma'arif Gedangan Tahun Ajaran 2018/2019" Doctoral Dissertation, Iain Salatiga. 2019.

Sulhan, Najib. Pembangunan Karakter Pada Anak Manajemen Pembelajaran Guru Menuju Sekolab efektif. Surabaya: Surabaya Intelektual Club, 2010.

Trianto. Model Pembelajaran Terpadu. Jakarta: PT Bumi Aksara, 2012.

Yunita, S. I. "Pengembangan Buku Saku Menulis Karangan Narasi Dengan Model Reciprocal Learning Untuk Kelas V Sdn Gugus Kartini Kabupaten Magelang" Doctoral Dissertation, Universitas Negeri Semarang. 2017.

Zuriah, N. Sunaryo, H., \& Yusuf, N. IbM Guru Dalam Pengembangan Bahan Ajar Kreatif Inovatif Berbasis Potensi Lokal. Dedikasi, Vol 13, (2016): 39-49. 